\title{
Letting Go of the Oil Addiction: Oil, Entrepreneurship and Franchising in Algeria
}

\author{
E. Hachemi Aliouche \\ University of New Hampshire \\ Dominique Bonet Fernandez \\ IPAG Business School
}

\author{
Manel Guechtouli \\ IPAG Business School
}

\author{
Widad Guechtouli \\ HEC Alger
}

\begin{abstract}
As an emerging country that is heavily dependent on oil revenues, Algeria is in urgent need of finding new ways of creating wealth. Entrepreneurship has been touted as an important way to create new wealth in emerging countries. Yet, the record of entrepreneurial development in Algeria is mixed at best. Franchising may be a key business model to develop the necessary entrepreneurial culture, skills and opportunities in Algeria and create new jobs and wealth on a large scale. However, to fully harness the potential of entrepreneurship and franchising as engines of economic development, Algeria needs to undertake major institutional reforms.
\end{abstract}

\section{INTRODUCTION}

Algeria is one of the largest economies in the Middle East and North Africa (MENA) region with a GDP of US\$646.4 billion and a population of 41.5 million in 2017 (IMF 2017). It is the largest country in Africa and the 10th largest country in the world by geographic size. It is relatively rich with natural resources, especially oil and natural gas. It has the $10^{\text {th }}$ largest natural gas reserves and the $16^{\text {th }}$ largest oil reserves in the world and it is the $6^{\text {th }}$ largest exporter of natural gas in the world (Algeria Economy 2018). Using its oil and natural gas wealth, Algeria succeeded in achieving a 20 percent poverty reduction in the past two decades, one of only a handful of countries to do so (World Bank, 2018). It was also able to maintain macroeconomic stability, amass large foreign currency reserves, and significantly reduce its external debt to about 2 percent of GDP (World Bank, 2018). Hydrocarbons (oil and natural gas) have played an outsize role in the Algerian economy. They still account for about 30 percent of GDP, 60 percent of budget revenues, and almost 95 percent of export earnings. Algeria is thus severely dependent on oil and gas. 
It is no surprise then that the large drops in oil prices in recent years have had a chilling effect on the Algerian economy. Since 2014, foreign reserves have fallen by more than US $\$ 35$ billion, the Oil Fund (Fond de Regulation des Recettes) has dropped by 30 percent, and the Algerian Dinar has lost over 30 percent of its value against the US dollar. For 2018, the IMF projects only a 0.8 percent growth in Algeria's real GDP (IMF 2018). This has reduced the government's ability to distribute rents and fund generous public subsidies, resulting potentially in increased social instability.

Its extreme dependence on oil and gas puts Algeria, its economy and its people at the mercy of the global energy markets. The reduction of Algeria's dependence on oil and gas has been a major objective of Algerian policy makers since the 1970s (Aliouche 1986). However, not much progress has been made as the country is still hopelessly dependent on oil and gas despite several economic reforms and initiatives, including liberalization of the economy and promotion of entrepreneurship (Bonet-Fernandez and Teulon 2014; Aliouche and Bonet-Fernandez 2017). Despite efforts to diversify the economy and promote entrepreneurship, the results are rather slim and entrepreneurial activities in Algeria are generally not significant enough to have an impact on Algeria's economic development. A major reason is the lack of an entrepreneurial culture and entrepreneurial and managerial skills. In this paper, we propose that a business model that has proved revolutionary in economically developed countries as well as in emerging countries - franchising - can help Algeria promote entrepreneurship, diversify its economy away from gas and oil, and boost its economic development.

In the next section, we present franchising and its various forms. Then we review franchising in emerging countries. We then discuss how franchising can help Algeria diversify its economy and reduce its heavy dependence on oil and gas.

\section{FRANCHISING AS ECONOMIC GROWTH ENGINE IN EMERGING COUNTRIES}

Franchising is a widespread business model that has revolutionized whole business sectors in economically developed as well as in emerging countries. In the United States, the country where franchising is most developed, franchising accounted in 2016, directly or indirectly, for 20.8 million jobs, and contributed over US\$1.3 trillion to US GDP. One out of every 12 Americans in the private sector worked in a franchised business or had a job because of franchising. 732,000 business establishments were franchised (PwC 2016).

Franchising has long been recognized as "a viable method of distributing goods and services which can have a positive influence on economic development" (Mendelsohn, 1992, p. 1). It is an effective business model for economic development and international integration in developing countries (Alon, 2004). The 1997 Consultative Survey on Franchising in the APEC Member Economies stated that "by supporting and encouraging the development of business format franchising, APEC governments can help the growth of small and medium enterprises. The franchising track record is full of examples of small businesses that grow and in turn foster other small businesses" (US Department of Commerce, 1997, p. 46).

Binh and Terry (2014) state that "because franchisors train operators in both technical and managerial aspects of business operations, it [franchising] is a particularly valuable strategy in developing countries to build a services-oriented economy" (p. 211). The franchise business model is an economic growth engine that allows franchised small businesses to grow at a faster rate, create more jobs, and produce higher sales growth than other businesses (IFA 2015).

The modern form of franchising developed in the United States with the launch of companies such as McDonald's, KFC, International House of Pancakes, etc. (Aliouche and Schlentrich 2015). We can now distinguish two major types of franchising: product and trade name franchising and business format franchising. In product and trade name franchising, the owner of a branded product or service (the franchisor) licenses its trademark and logo to independent businesses (the franchisees) who can then sell its products or services. This franchise model is prevalent in soft drinks (Coca-Cola, Pepsi-Cola, etc.), automobiles (Ford, Toyota, etc.), and gasoline distribution (Shell, Mobil, BP, etc.). In the business format franchising model, on the other hand, the relationship between the franchisor and its franchisees is much 
more involved. In addition to licensing its brand and logo to its franchisees and allowing them to sell its products and services, the franchisor also provides them with numerous other services and information that will enable them to successfully operate their businesses: an operations manual, a marketing plan, training, ongoing technical and managerial support, etc. To join the franchise network, franchisees pay the franchisor a franchise fee and ongoing royalty payments (a percentage of sales revenues) (Aliouche and Bonet Fernandez 2017). Though the product and trade name franchising model was very popular in the early days of franchising, business format franchising is now the more dominant model in economically developed countries. In the United States in 2016, there were eleven times as many establishments and more than five times as many jobs in business format franchising than in product and trade name franchising (PwC 2016).

An entrepreneurial business can grow by building and operating its own units or by franchising. Franchising allows this business to grow much faster by using the resources the franchisees bring: capital, motivated managerial talent, and local knowledge. Franchising also allows a business to mitigate the agency problems that may arise, especially when expanding internationally.

A budding entrepreneur can start his/her own business venture as an independent business or join an established franchise network as a franchisee. For a new entrepreneur, the benefits of becoming a franchisee are compelling as he/she "can go into business for him/herself but not by him/herself." (Besthel, 2001). Joining an established franchise network allows the entrepreneur (franchisee) to use an established brand; join a proven business concept; take advantage of franchisor-provided technical and managerial support and assistance in key areas such as site selection, facility design and layout, inventory purchasing and control, equipment purchasing or leasing, training, quality control standards, marketing support, etc. (Aliouche and Bonet Fernandez 2017).

Though product and trade name franchising and business format franchising are currently the dominant franchise models, other forms of franchising have been developed, including tandem franchising, microfranchising, social franchising, community franchising, flexible franchising, and quasifranchising. Tandem franchising is a form of "cooperative entrepreneurship" that helps individuals from disadvantaged backgrounds become franchisees through funding and mentoring programs (du Toit 2007, Hoy and Shane 1996). Microfranchising is a form of franchising on a small scale that requires much lower costs. Social franchising is franchising with a social purpose. It applies franchising principles to achieve social objectives (Aliouche and Schlentrich 2015). Community franchising is a form of franchising where a community rather than an individual is the franchisee. Flexible franchising is a form of franchising where franchisees have significant levels of autonomy. In quasi-franchising, the franchisee uses the proven franchise system's back of the house functions, but does not use its front-of the house features such as the brand name and the unit design (Terry and Di Lernia 2013).

\section{FRANCHISING DEVELOPMENT IN ALGERIA}

At the micro level, franchising is a business model that can help business firms grow faster and more efficiently. It also allows individual entrepreneurs, even those with only limited business experience, to start a business with less risk, and with a support system that helps them succeed. At the macro level, franchising helps a country in major ways, including job creation, increased output of goods and services, economic modernization, infrastructure development, faster economic growth, development of entrepreneurial culture, development of entrepreneurial and managerial skills, business innovation, economic efficiency, labor force training, higher labor productivity, more consumer choices, increased product and services quality, and increased tax base (Alon 2004). These features and benefits of franchising can have a marked positive impact on Algeria's quest for economic diversification, reduced reliance on oil and gas, and overall economic growth. The benefits most attractive to Algeria include increased output of goods and services in non-oil and gas sectors, job creation, economic modernization, promotion of entrepreneurship, and acquisition of skills (entrepreneurial, managerial, etc.).

Franchising is particularly suited for the development of the services sectors. It is a pervasive model in dozens of service businesses, including food services, lodging, automotive, retail, maintenance, 
personal care, home improvement, financial services, technical services, recreation, etc. The development of franchising in Algeria will help grow existing business services and develop new ones currently not available in the country. This will undoubtedly help diversify the national economy and help reduce the heavy dependence on the oil and gas sectors.

The job creation and economic growth potential of franchising is well-documented (Preble and Hoffman 1995; Alon and Welsh 2001; Welsh and Alon 2001; PwC 2016). A study focusing on African franchisors found that each franchisor created on average about 32 direct jobs per year (Siggel, Maisonneuve, and Fortin 2003). A 2003 IFA study found that franchising had created a sizable number of jobs in many emerging countries: 530,000 in South Korea, 226,334 in Brazil,100,000 in the Philippines, 80,000 in Malaysia, etc. (IFA 2003). Algeria is faced with a serious youth unemployment challenge that poses risks for the social stability of the country (Aliouche and Bonet-Fernandez 2017). In 2014, the youth unemployment rate was 28.4 percent (CIA World Factbook 2015). As in other countries, the development of franchising in Algeria will create a substantial number of jobs from entry-level low skills jobs to more sophisticated managerial and entrepreneurial jobs. This employment and the incomes it provides will spur additional domestic demand for goods and services, further promoting economic growth and additional job creation, mostly in the non-oil and non-gas sectors of the economy.

In emerging countries, franchising usually grows through the implantation of international franchisors and then the development of local franchise systems (Aliouche et al. 2015). International franchisors bring world class quality standards, business methods, and infrastructure. As they expand into Algeria, international franchisors will propagate their know-how and world class methods and standards, motivating Algerian businesses and entrepreneurs to learn and adopt these. Algerian businesses, entrepreneurs, franchisors, franchisees, and employees will become more efficient and more competitive, benefitting the whole economy.

A major benefit of franchising is its capacity to encourage local entrepreneurship and to develop small and medium-sized enterprises (SMEs). Franchisees are essentially entrepreneurs and their companies are SMEs. Franchise pioneer William Rosenberg, the founder of Dunkin Donuts, famously said that "... franchising is the epitome of entrepreneurship" (Rosenberg 2001). Franchising provides individuals the opportunity to own their own businesses.

The 2003 IFA study cited earlier found that in many emerging countries, franchising allowed the emergence of large numbers of franchisors and franchisees: 1,300 franchisors and 120,000 franchisees in South Korea; 894 franchisors and 46,534 franchisees in Brazil; 500 franchisors and 4,000 franchisees in the Philippines, 225 franchisors and 6,000 franchisees in Malaysia, etc. (IFA 2003). Likewise, given the appropriate environment and encouragement, significant numbers of franchisors and franchisees could emerge in Algeria, helping to spread the entrepreneurial culture and entrepreneurial skills in a number of non-oil and non-gas industries.

The development of franchising in an emerging country can help improve the quality of its work force. Typically, international franchisors provide training to local franchisees and their employees as part of business format franchising. In addition to training on the equipment needed to run the franchised unit, international franchisors may also transfer operative capabilities, investment capabilities, and innovative capabilities, and other resources and knowledge to franchisees and employees in emerging countries (Stanworth, Price, and Purdy 2001; Alon 2004). These transfers raise the skills levels of local franchisees and employees and make them more productive. Local entrepreneurs, even those not in franchised businesses, can also learn from international franchisors and imitate their methods and standards, thus improving their own skills and businesses. Franchising, thus, may help Algerian entrepreneurs, franchisees, and employees improve their skills and raise their productivity and competitiveness.

To transition from an emerging country where franchising is still at the embryonic stage (Aliouche $e t$ al., 2015) to an economy where franchising thrives, Algeria will have to proceed by stages and will need to undertake significant institutional reforms. As for many emerging countries, business format franchising, the most widespread franchising model in economically developed countries, may not be the best way to promote franchising in Algeria at this time. Though it is a model to aspire to, business format franchising requires a supportive institutional environment that currently is not available in Algeria 
(Bonet-Fernandez and Teulon 2014; Aliouche et al. 2015; Aliouche 2015). According to the International Franchise Expansion Index, Algeria was ranked \#84 out of 125 countries in terms of attractiveness as an international expansion market for US franchise companies in 2015. This is mainly due to its very poor ranking in terms of legal and regulatory environment where it is ranked \#111 out of 125 countries (Aliouche 2017). While improving its institutional infrastructure, Algeria may start promoting franchising by first focusing, as appropriate, on one or more of the forms of franchising mentioned earlier, such as tandem franchising, microfranchising, social franchising, and particularly (at least initially) product and trade name franchising. Faced with somewhat similar institutional challenges, Vietnam has nevertheless been able to develop a fast-growing franchise sector, expanding the number of franchise systems from 32 in 2006 to 116 in 2012. Over this time period, the number of its domestic franchisors doubled from 10 to 20 (Binh and Terry 2014). Some of its domestic franchisors, such as Trung Nguyen Coffee and Pho 24, have grown significantly and have now expanded overseas. Trung Nguyen Coffee now has over 1,000 outlets across all 63 provinces in Vietnam, and it has expanded to over 40 countries, including China, Germany, Malaysia, and the United States. It has expanded its franchising operations mainly through product and trade name franchising and flexible franchising (Binh and Terry 2014).

Algeria can also benefit from another emerging country's experience with franchising. At the Franchise International Malaysia conference in August 2000, the Malaysian Deputy Prime Minister said that "...franchising is one mode of entrepreneurship that can help us achieve higher standards not only in the goods and services offered, but also in upgrading effective management systems and skills... Franchising ensures immediate entry, the learning period is shortened, and the rate of success is enhanced. Franchising can also be used as an instrument to enable the transfer of technology from systems developed elsewhere. We will be able to benefit from such transfer." (Di Lernia and Terry 2017, p. 66). By 2003, Malaysia had 225 franchisors and 6,000 franchisees that generated US $\$ 5.0$ billion in annual sales and created 80,000 jobs (IFA 2003).

\section{CONCLUSIONS}

The recent sharp drops in oil prices threatens to have a severe impact Algeria's economy and society. The heavy dependence of Algeria on its oil and gas sectors makes it very vulnerable to events in the global markets. Franchising can offer Algeria a way to diversify its economy, reduce its dependence on oil and gas, promote an entrepreneurial culture, develop entrepreneurial and managerial skills, modernize important sectors of its economy, and accelerate its economic development. Several emerging countries, including Brazil, South Korea, Malaysia, Vietnam, etc., have embraced and promoted the franchise business model and have benefitted. These experiences and Algeria's need for economic diversification should motivate Algerian policymakers to recognize and promote franchising as an important development strategy. However, to fully harness the potential of franchising, Algeria needs to urgently undertake legal, regulatory and institutional reforms.

\section{REFERENCES}

Algeria Economy (2018). Retrieved from https://theodora.com/wfbcurrent/algeria/algeria_economy.html. Aliouche, E.H. (2017). International Franchising: Optimal Market Selection. In Terry A., Hoy F. and Perrigot R. (editors), The Edward Elgar Handbook on Franchising.

Aliouche E.H., \& Bonet Fernandez D. (2017). Social Entrepreneurship and Franchising: A Panacea for Emerging Countries? In G. Gendrikse, G. Cliquet, T. Ehrmann, J. Wndsperger (Ed.), Management and Governance of Networks: Franchising, Cooperatives and Strategic Alliances. Springer.

Aliouche E.H., (2015). The Impact of the Global Financial Crisis on Country Attractiveness. Thunderbird International Business Review, 57(1), 63-83. 
Aliouche, E.H., Bonet Fernandez D., Chanut, O. and Gharbi N. (2015). Institutional Environments and the Internationalization of Franchise Chains: The Contrasting Cases of Three North African Countries. Journal of Applied Business Research, 31(2), 417-436.

Aliouche, E.H., \& Schlentrich, U. (2015). Social Franchising. In Brookes, M. and Altinay, L. (editors) Entrepreneurship in Hospitality and Tourism: A Global Perspective, Goodfellow Publishers (United Kingdom). September 2015.

Aliouche, E.H. (1986). Heavy Industrialization: The Algerian Experience. In R. W. England (editor) Economic Processes and Political Conflicts: Contributions to Modern Political Economy, Praeger, New York.

Alon, I. (2004). Global Franchising and Development in Emerging and Transitioning Markets. Journal of Macromarketing 24 (2), December, 156-167.

Alon, I., \& Welsh, D.H.B. (2001). International Franchising in Emerging Markets: China, India, and Other Asian Countries. Chicago: $\mathrm{CCH}$ Publishing.

Besthel, B. (2001). An Introduction to Franchising. IFA Educational Foundation and the Pepsi Foundation: Washington, DC.

Bonet Fernandez, D., \& Teulon, F. (2014). L'Algérie en Quête d'un Nouvel Avenir. Ipag Economics \& Management Letters, No. 4,5,6. Retrieved from http://www.ipag.fr/wp-content/upload/2014/03/Letter_2014-04;pdf http://www.ipag.fr/wp-content/upload/2014/03/Letter 2014-05;pdf http://www.ipag.fr/wp-content/upload/2014/03/Letter 2014-06;pdf

Binh N.B. and Terry A. (2014). Meeting the Challenges for Franchising in Developing Countries: The Vietnamese Experience. Journal of Marketing Channels, 21: 210-221.

CIA World Factbook (2015)

Di Lernia C. and Terry A. (2017). Beyond Main Street: Franchising Strategies for Indigenous Entrepreneurship in Australia. In G. Gendrikse, G. Cliquet, T. Ehrmann, J. Wndsperger (Ed.), Management and Governance of Networks: Franchising, Cooperatives and Strategic Alliances. Springer.

du Toit A. (2007). The Financing and Mentoring of Emerging Franchisees Through Tandem Franchising, $3^{\text {rd }}$ International Conference on Economics and Management of Networks, June 2007, Rotterdam.

Hoy F. and Shane S.A. (1996). Franchising as an Entrepreneurial Venture Form. Journal of Business Venturing 13:91-94.

IFA (2003). International Franchise Association, http://franchise.org.

IFA (2015). International Franchise Association, http://franchise.org.

IMF (2017). Retrieved from

http://www.imf.org/external/datamapper/PPPGDP@WEO/OEMDC/ADVEC/WEOWORLD/DZ A/MEQ.

IMF (2018). Retrieved from http://www.imf.org/en/Countries/DZA.

Mendelsohn M. (1992). The Guide to Franchising ( $5^{\text {th }}$ edition). London, UK: Cassell.

Preble J.F. and Hoffman R.C. (1995). International Note: Franchising Systems around the World: A Status Report. Journal of Small Business Management, 33(2), 80-88.

PwC (2016), The Economic Impact of Franchised Businesses: Volume IV, 2016 (Prepared for the IFA Education and Research Foundation). Retrieved from https://www.franchise.org/sites/default/files/Economic $\% 20$ Impact $\% 20 \mathrm{of} \% 20$ Franchised $\% 20 \mathrm{Busi}$ nesses Vol\%20IV 20160915.pdf.

Rosenberg W. (2001). Time to Make the Donuts. Lebhar-Friedman Books, NY.

Siggel E., Maisonneuve P. and Fortin E. (2003). The Role of Franchising in African Economic Development. Paper presented at the $17^{\text {th }}$ Annual Conference of the International Society of Franchising, San Antonio, Texas.

Stanworth J., Price S., \& Purdy D. (2001). Franchising as a Source of Technology Transfer to Developing Economies. In International Franchising in Emerging Markets: Central and Eastern Europe and Latin America, edited by Welsh D. and Alon I. 87-104. Chicago: CCH Publishing. 
Terry, A., \& Di Lernia C. (2013). Quasi-franchising: A New Model for Strategic Business Cooperation. In: Wndsperger J., Ehrmann T., Cliquet G., Gendrikse G. (Ed.), Network Governance: Alliances, Cooperatives and Franchise Chains. Physica-Verlag. Heildelberg, pp. 269-286.

US Department of Commerce (1997). Consultative Survey on Franchising in the APEC Member Economies. August.

World Bank (2018). Retrieved from http://www.worldbank.org/en/country/algeria. 